\title{
Manufaktura metodoen eta saretze-erreakzioaren eragina gelatinazko materialen propietateetan
}

\author{
Effect of manufacturing methods and crosslinking reaction \\ on the properties of gelatin materials
}

\author{
Alaitz Etxabide*, Jone Uranga, Pedro Guerrero, Koro de la Caba \\ BIOMAT ikerketa-taldea, Gipuzkoako Ingeniaritza Eskola, \\ Donostia, Euskal Herriko Unibertsitatea (UPV/EHU)
}

\begin{abstract}
LABURPENA: Plastikoen erabilerak eta haien zabor-tratamenduak sortutako kezkek jasangarriagoak diren iturrien erabilera bultzatzeko ordezko materialen garapena sustatu dute. Azkeneko urteotan, proteinen ikerketaren arloan gelatinan oinarritutako materialenganako interesa handitu da. Proteinen merkatu-bideragarritasuna sustatzeko helburuarekin, gelatinazko filmak, scaffold-ak eta biokonpositeak prestatu ziren, hurrenez hurren disoluzio metodoaren bidez, liofilizazioz eta estrusio-injekzio tekniken bidez. Gainera, gelatinaren urarekiko sentikortasuna txikitzeko, materialak laktosarekin erreakzionarazi zituzten, Maillard saretze-erreakzioa bero tratamendu bidez bultzatuz $\left(105{ }^{\circ} \mathrm{C}, 24 \mathrm{ordu}\right)$. Fourierren transformatuaren bidezko espektroskopia infragorriaren (FTIR) bidez gelatinaren eta laktosaren arteko interakzioak baieztatu ziren. Bestetik, gelatinazko materialen ura xurgatzeko gaitasunen balio ezberdinek eta ekorketazko elektroi-mikroskopia (SEM) bidez ikusitako egitura desberdinek saretze erreakzioak eta manufaktura prozesuek materialen propietateetan eragin zutela baieztatu zuten.
\end{abstract}

HITZ GAKOAK: gelatina, laktosa, saretze erreakzioa, manufaktura teknikak.

\begin{abstract}
Concerns about the usage and disposal of plastics have promoted the development of alternative materials to address a more sustainable use of resources. In recent years, in the specific field of proteins' research, the interest in gelatin-based materials has increased. With the aim of promoting proteins' market viability, gelatin films, scaffolds and biocomposites were prepared by solvent casting, freeze-drying and extrusion-injection techniques, respectively. Furthermore, in order to reduce the water sensitivity of gelatin, materials were crosslinked with lactose, promoting the Maillard reaction by means of a heating process $\left(105{ }^{\circ} \mathrm{C}, 24 \mathrm{~h}\right)$. Fourier transform infrared (FTIR) spectroscopy was used to confirm the interactions between gelatin and lactose. The values of water uptake capacity and the structures observed by SEM showed the effect of the crosslinking reaction and manufacture process on the gelatin-based materials' properties.
\end{abstract}

KEYWORDS: gelatin, lactose, crosslinking reaction, manufacturing methods.

\footnotetext{
* Harremanetan jartzeko / Corresponding author: Alaitz Etxabide, BIOMAT ikerketa-taldea, Ingeniaritza Kimikoa eta Ingurumenaren Ingeniaritza Saila, Gipuzkoako Ingeniaritza Eskola, Euskal Herriko Unibertsitatea (UPV/EHU), Europa Plaza, 1, 20018 Donostia-San Sebastián, Espainia. - alaitz.etxabide@ehu.eus - https://orcid.org/0000-0002-8025-0717.

Nola aipatu / How to cite: Etxabide, Alaitz; Uranga, Jone; Guerrero, Pedro; De la Caba, Koro (2019). «Manufaktura metodoen eta saretze-erreakzioaren eragina gelatinazko materialen propietateetan»; Ekaia, 35, 2019, 71-84. (https://doi.org/10.1387/ ekaia.19635).

Jasoa: 11 maiatza, 2018; Onartua: 4 uztaila, 2018.

ISSN 0214-9001 - eISSN 2444-3255 / (c) 2019 UPV/EHU
}

cc)(i) () Obra hau Creative Commons Atribución 4.0 Internacional-en lizentziapean dago 


\section{SARRERA}

Plastikoek eguneroko bizitza eraldatu dute, eta onura ugari ekarri dizkiote gizarteari. Hala ere, plastikoen erabilerak eta haien zabor-tratamenduak sortutako kezkek jasangarriagoak diren iturrien erabilera bultzatzeko ordezko materialen garapena sustatu dute, ekonomia zirkularraren kontzeptuarekin bat etorriz [1]. Azken urteotan, iturri berriztagarrietatik eratorritako polimero biodegradagarriak, hala nola, nekazaritza-industriako eta itsasoko hondakin eta azpi-produktuak, petroliotik eratorritako polimeroak ordezkatzeko aukera jasangarritzat hartu dira [2]. Gainera, konposatu toxikoen presentziagatik kontsumitzaileen osasunaren inguruan sorturiko kezkek sintetikoak diren konposatuak naturalak diren substantziak ordezkatzeko interesa areagotu dute [3, 4]. Hori dela eta, zenbait aplikaziotan, hala nola, elikagaiak babesteko eta biomaterialak sortzeko, abantaila izan daiteke biopolimero eta gehigarri naturalen erabilera ingurumenaren jasangarritasunerako eta kontsumitzaileen onargarritasunerako. Landare eta animalietatik eratorritako material biodegradagarriek eta jangarriek, hala nola, proteinek, polisakaridoek eta lipidoek, ontzi edota biomaterial moduan erabiltzeko ahalmena erakutsi dute $[5,6]$.

Biopolimeroen artean, proteinen ugaritasunagatik, filma sortzeko gaitasunagatik, gardentasunagatik eta $\mathrm{O}_{2}, \mathrm{CO}_{2}$ eta lipidoen kontrako hesi-propietate bikainengatik, proteinak elikagaien paketatze-produkziorako ezaugarri baliagarriak eskaintzen dituzten lehengaiak dira [7]. Horretaz gain, proteinen biobateragarritasunagatik, biodegradagarritasunagatik, eta propietate biologikoak hobetzen dituen zelulen itsaspena sustatzeko gaitasunagatik, proteina biomaterial moduan erabiltzeko materiala kontsidera daiteke [8]. Gainera, proteinak heteropolimeroak direnez, talde funtzional ugari dituzte, eta, ondorioz, proteinetan oinarritutako materialen propietateak aldakuntza entzimatiko, kimiko edota fisikoen bidez eralda daitezke, aplikazio jakinetan behar diren amaierako propietateak lortzeko [9]. Horretaz gain, aipatzekoa da proteinetan oinarritutako materialak konposatu antioxidatzaileak, antimikrobiarrak, antifungikoak eta zaporedun konposatuak eramateko garraiatzaile bikainak izan daitezkeela [10].

Azkeneko urteotan, handitu egin da proteinen ikerketaren arloan gelatinan oinarritutako materialei buruzko interesa [11]. Gelatina animalia-proteina bat da, lur eta itsasoko animalien hezur, azal eta ehun konektiboetako kolagenoari egindako hidrolisitik lortzen dena. Gelatinen artean, arrazoi sozio-kulturalak direla eta, arrain-gelatinak arreta erakarri du ugaztun-gelatinen ordez erabiltzeko [12]. Gelatinen ugaritasunak, erabilgarritasunak eta kostu baxuak material hau aplikazio ugaritan erabiltzera bultzatzen dute. Gelatina elikagai zaporegabea, biobateragarria, biodegradagarria eta ez-to- 
xikoa izateaz gain, kolagenoa baino konposatu antigeniko gutxiago aurkezten ditu, elikagaiak babesteko filmetan edota biomaterialetan erabiltzeko ahalmen handia erakutsiz $[13,14]$.

Gelatinaren berezko hidrofilotasunagatik, proteina honetan oinarritutako materialek hauskortasun eta urarekiko sentikortasun handia erakusten dute, hauen erabilera zenbait aplikaziotara mugatuz. Propietate funtzional hauen hobekuntza proteinaren saretze bidez lor daiteke [15-17]. Gelatinaren saretze kimikoa propietate kimiko eta fisiko hobeak dituen materialak lortzeko bide eraginkorra izan daiteke. Azetilazioa, deamidazioa eta proteinen propietate funtzionalak hobetzeko eskuragarri dauden beste metodo kimikoekin alderatuz, Maillard erreakzioa beroarekin bizkortzen den saretze-erreakzioa da. Nahiz eta literaturako lan gehienak Maillard erreakzioan sortutako konjugatuen propietate biologikoetan kontzentratu diren, Maillard erreakzioa proteinen beste propietate funtzionalak hobetzeko etorkizun handiko metodoa izan daiteke. Maillard erreakzioaren proportzioa faktore batzuen menpe dago, hala nola, tenperatura, denbora, proteina: karbohidrato ratioa eta $\mathrm{pH}-\mathrm{a}$ [18]. Lan honetan, $\mathrm{pH}$ basikoan prestatutako \% 20 laktosadun materialen karakterizazioa egin da.

Gelatinan oinarrituriko materialak prestatzerakoan ,berriz, plastikoen industrian erabilitako zenbait fabrikatze-metodo erabili dira. Gelatinaren urarekiko disolbagarritasun handia eta tenperaturarekiko urtze-puntu baxua abantailatzat hartuz, gelatina disoluzio metodoaren bidez, liofilizazioz eta estrusio-injekzio bidez prozesatu da proteinaren merkatu-bideragarritasuna sustatzeko helburuarekin. Beraz, artikulu honetan arrain-gelatinazko filmak, scaffold-ak eta biokonpositeak ekoizteaz gain, materialen berokuntza bidez egindako erreakzio kimikoa sustatzeko formulazioan laktosa gehitu da. Saretze-erreakzioa, handitzea eta egitura - propietateak Fourierren transformatuaren espektroskopia infragorria (FTIR), ekorketazko elektroi-mikroskopioa (SEM) eta ura xurgatzeko gaitasunaren bidez aztertu dira.

\section{MATERIALAK ETA METODOAK}

\subsection{Materialak}

Erabilitako arrain-gelatina Weishardt Internationalek (Eslovakia) ekoiztutakoa da. Gelatinak \% 11,06ko hezetasuna dauka, 200eko bloom-a eta \% 0,147ko errautsak ditu. Ezaugarri azidoak ditu eta haren puntu isoelektrikoa 5,09 da. Glizerola plastifikatzaile gisa eta laktosa saretze-erreaktibo gisa erabili dira, eta biak Panreacek (Bartzelona) ekoitziak dira. 


\subsection{Filmen, scaffold-en eta biokonpositeen prestaketa}

\subsubsection{Filmen prestaketa}

\% 20 laktosa kantitatezko (gelatina idorrarekiko portzentajea) gelatinazko filmak disoluzio metodoa erabiliz prestatu ziren. Lehenengo, $100 \mathrm{~mL}$ ur destilatuan disolbatu ziren arrain-gelatina $5 \mathrm{~g}$ eta $1 \mathrm{~g}$ laktosa, nahastea berogailu magnetiko batean $80{ }^{\circ} \mathrm{C}$-an eta 200 bira minutuko abiaduran 30 minutuz irabiatzen utziz. Ondoren, \% 10 glizerola (gelatina idorrarekiko) disoluzioan gehitu zen, eta $1 \mathrm{~N} \mathrm{NaOH}$-rekin disoluzioaren $\mathrm{pH}-\mathrm{a}$ 10 ,0era egokitu zen, nahastea beste 30 minutuz $80^{\circ} \mathrm{C}$-an irabiatzen utziz. Gero, filma eratzeko soluziotik $17 \mathrm{~mL}$ Petri ontzi bakoitzean isuri ziren, eta haiek 48 orduz giro-tenperaturan lehortzen utzi ziren filmak lortzeko (1. irudia).

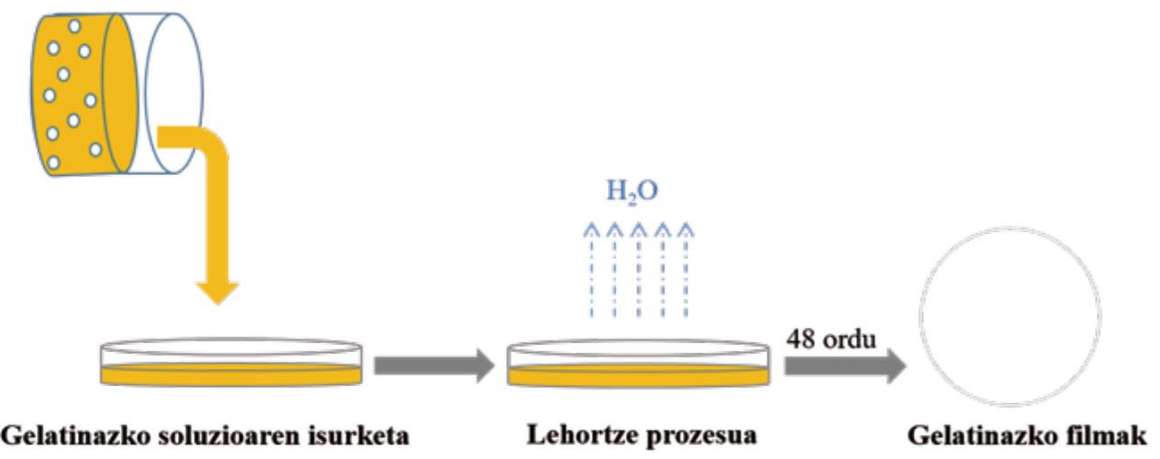

1. irudia. Gelatinazko filmak lortzeko disoluzio metodoaren prozesua.

\subsubsection{Scaffold-en prestaketa}

$\% 20$ laktosadun (gelatina idorrarekiko portzentajea) $\% 2,5$ eta $\% 4,0$ gelatinazko soluzioak prestatzeko, 2.2.1 ataleko pausuak jarraitu ziren. Behin gelatinazko soluzioak prestatuta, soluzioetatik $2 \mathrm{~mL} 24$ zulodun platereko (Costar 3526, Corning Incorporated, USA) zulo bakoitzean isuri ziren eta platera izozkailuan $-20{ }^{\circ} \mathrm{C}$-tan 48 orduz utzi zen, ondoren beste 48 orduz liofilizatzeko (Alpha 1-2 LDplus, CHRIST, Alemania) eta azkenik scaffold-ak lortzeko (2. irudia). 


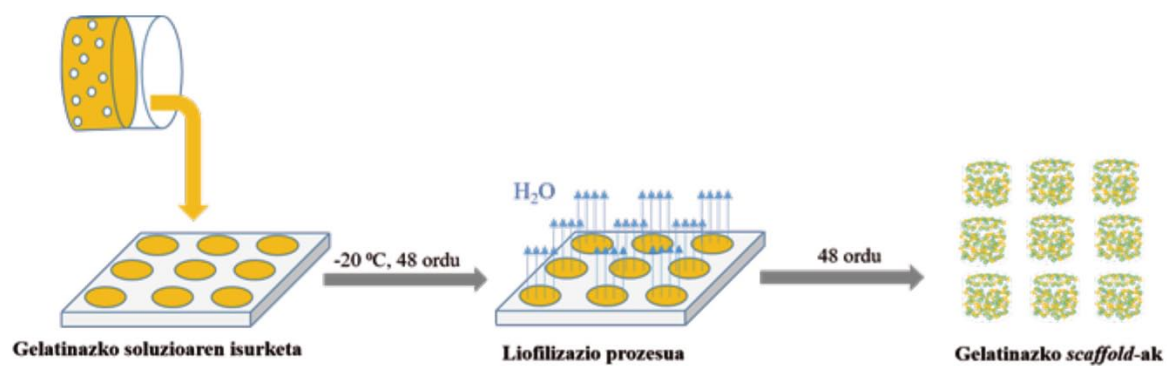

2. irudia. Gelatinazko scaffold-ak lortzeko liofilizazio prozesua.

\subsubsection{Biokonpositeen prestaketa}

Batera biratzen diren torloju bikoitzeko estrusio-makina, Thermo Haake MiniLab II (Thermo Fisher Scientific) mikro nahasgailua, gelatinazko xaflak sortzeko erabili zen. Estrusio-elikadura $40 \mathrm{~g}$ gelatina, \% 10 glizerola (gelatina idorrarekiko ehunekoa) eta \% 20 laktosa kantitate (gelatina idorrarekiko) $1 \mathrm{~N} \mathrm{NaOH}$ erabiliz, $\mathrm{pH}-\mathrm{a}$ 10,0era egokitutako ur destilatuan (\% 50, gelatina idorrarekiko) nahasiz prestatu zen. Ondoren, estrusio-makina $1,6 \mathrm{~g} / \mathrm{min}$-ko abiaduran elikatu zen, estrusio-zilindroaren tenperatura $90{ }^{\circ} \mathrm{C}$-an zehaztu zen, torlojuaren abiadura 70 bira minutuan egokitu zen, eta momentuaren balioak 25 eta $30 \mathrm{~N} \cdot \mathrm{cm}$ bitartekoak izan ziren.

Xaflak giro-tenperaturan hoztu ondoren, gelatinazko laginak lauki txikitan moztu ziren eta ondoren, pelletak injektatu ziren. Thermo Haake MiniJet II (Thermo Fisher Scientific) injektorea arrain-gelatinazko biokonpositeak lortzeko erabili zen (3. irudia).

Horretaz gain, lorturiko filmak, scaffold-ak eta biokonpositeak $105{ }^{\circ} \mathrm{C}$-an 24 orduz labean berotu ziren (HT), kimikoki saretutako materialak lortzeko. Erreferentziatzat berotu gabeko $(\mathrm{NH})$ materialak erabili ziren. Azkenik, laginak aztertu aurretik, hauek ganbera klimatiko batean $25^{\circ} \mathrm{C}$-an eta $\% 50$ eko hezetasun erlatiboko baldintzapean gorde ziren 48 orduz. 


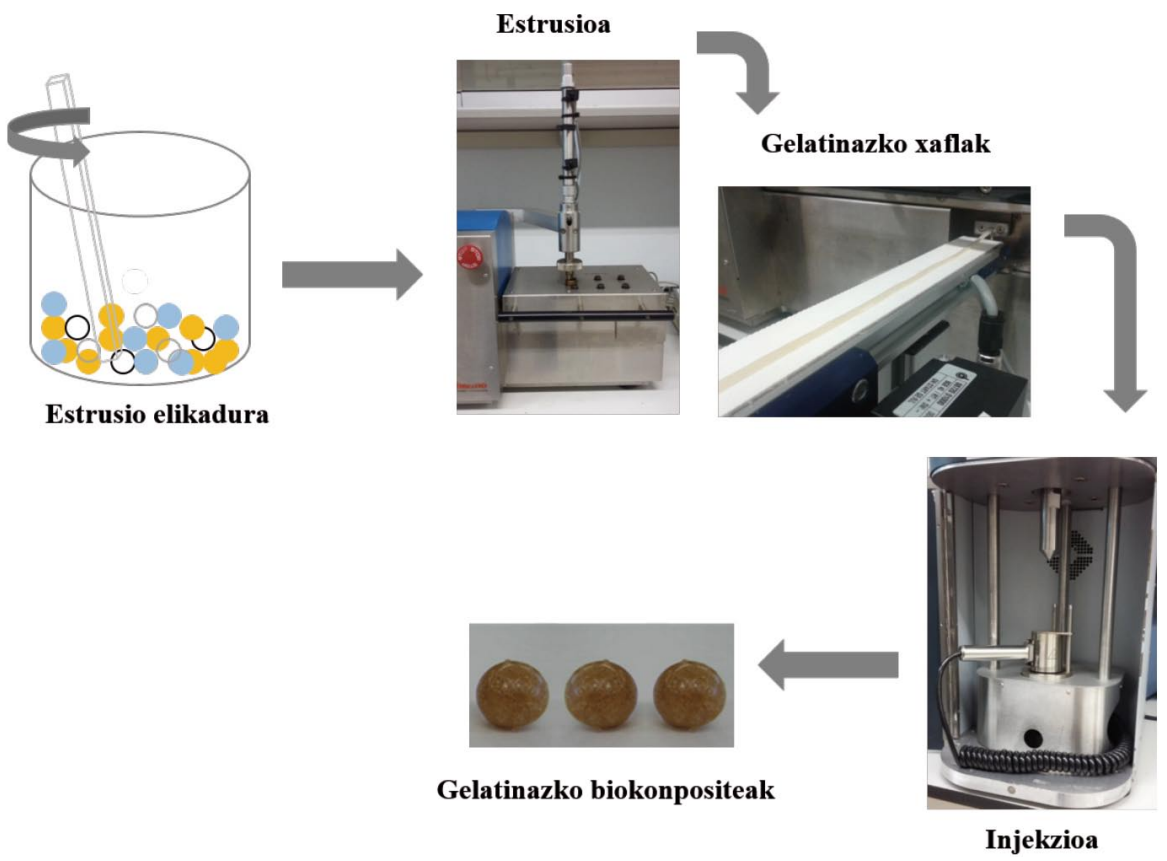

3. irudia. Gelatinazko biokonpositeak lortzeko estrusio-injekzio teknika bidezko prozesua.

\subsection{Fourierren transformatuaren bidezko espektroskopia infragorria (FTIR)}

Gelatinaren eta laktosaren arteko saretze-erreakzioa aztertzeko, FTIR analisia Nicolet Nexus FTIR espektrofotometroan burutu zen (Thermo Scientific), Golden Gate (Specac) ATR osagarria erabiliz. Guztira, 32 ekorketa egin ziren, $4 \mathrm{~cm}^{-1}$-eko erresoluzioarekin. Neurketak 4000 eta $800 \mathrm{~cm}^{-1}$ eko tartean egin ziren.

\subsection{Ekorketazko elektroi-mikroskopia (SEM)}

Haustura-gainazalaren morfologia bistaratzeko, emisio-eremuzko Hitachi S-4800 (Hitachi High-Technologies Corporation) ekorketazko elektroi-mikroskopioa $15 \mathrm{kV}$-tan erabili zen. Konposizio bakoitzeko laginak bi aldeko zinta itsasgarriaren laguntzaz metalezko oinarrian kokatu ziren, eta behaketa aurretik urrez estali ziren (JFC-1100) argoizko ingurune hutsean. 


\subsection{Ura xurgatzeko gaitasuna}

Gelatinazko materialen ura xurgatzeko gaitasuna analisi grabimetriko bidez aztertu zen, ASTM D570-98 [19] arauari jarraituz. Fabrikazio metodo ezberdinez lorturiko material bakoitzeko hiru lagin pisatu ziren $\left(\mathrm{W}_{0}\right)$ eta $\mathrm{pH} 7$ zuen fosfato buffer soluzio gazian (PBS) laginak murgildu ziren. Ondoren, denbora zehatz batzuetan laginak buffer soluziotik atera, paperezko zapi batekin lehortu eta berriro ere pisatu ziren $\left(\mathrm{W}_{\mathrm{t}}\right)$. Prozesua handitze-balio konstanteak lortu arte errepikatu zen. Ura xurgatzeko gaitasuna (S) honako ekuazio hau erabiliz kalkulatu zen [20]:

$$
S(\%)=\frac{\left(W_{t}-W_{0}\right)}{W_{o}} \times 100
$$

Ura xurgatzeko gaitasuna (S) denborarekiko (t) irudikatzen duen grafikoa marraztu zen, S-ren oreka determinatzeko.

\section{EMAITZAK ETA EZTABAIDA}

\subsection{Fourierren transformatuaren bidezko espektroskopia infragorria (FTIR)}

Maillard erreakzioan gertatutako gelatinaren eta laktosaren arteko interakzioak aztertzeko, FTIR espektroskopia bidez materialetan gertatutako aldaketa kimikoak aztertu ziren, eta espektroak 4. irudian erakusten dira. Manufaktura metodo ezberdinak erabili arren, prozesu guztietan erreaktibo (gelatina, laktosa eta glizerola) berak erabili zirenez, kasu guztietan espektro berak lortu ziren, eta ondorioz, 4. irudian filmen espektroak bakarrik agertzen dira. Erreaktiboen egitura kimikoak 1. eskeman erakusten dira. Gelatinaren xurgatze-banda nagusiak $1.630 \mathrm{~cm}^{-1}$-eko $\mathrm{C}=\mathrm{O}$ loturaren luzatzearekin (amida I), $1530 \mathrm{~cm}^{-1}$-eko N-H loturaren tolestearekin (amida II) eta $1.230 \mathrm{~cm}^{-1}$-eko C-N loturaren luzatzearekin (amida III) erlazionatu ziren [21]. Laktosari atxikitako xurgatze-banda nagusiak 1180 eta $953 \mathrm{~cm}^{-1}$ artean kokatu ziren; 979 eta $987 \mathrm{~cm}^{-1}$-eko bandak C-C loturaren bibrazioari egokitu zitzaizkion, eta $1.034 \mathrm{~cm}^{-1}$-eko banda $\mathrm{CH}_{2}-\mathrm{OH}$ taldearen $\mathrm{C}-\mathrm{O}$ loturaren bibrazioekin erlazionatu zen [22]. Azkenik, glizerolaren banda nagusiak, 850,940 eta $1.000 \mathrm{~cm}^{-1}$-eko C-C loturen eta 1.050 eta $1.100 \mathrm{~cm}^{-1}$-eko $\mathrm{C}-\mathrm{O}$ loturen bibrazioekin erlazionatu ziren [23]. 4b irudian hobeto ikus daitekeen moduan, 1.100-1.000 $\mathrm{cm}^{-1}$-eko tartean kokaturiko bi bandek banda bakarra osatzeko joera erakutsi zuten bero tratamenduaren (HT) ostean, Maillard erreakzioaren hedapenak gelatinazko materialen aldaketa kimikoak eragin zituela adieraziz. 


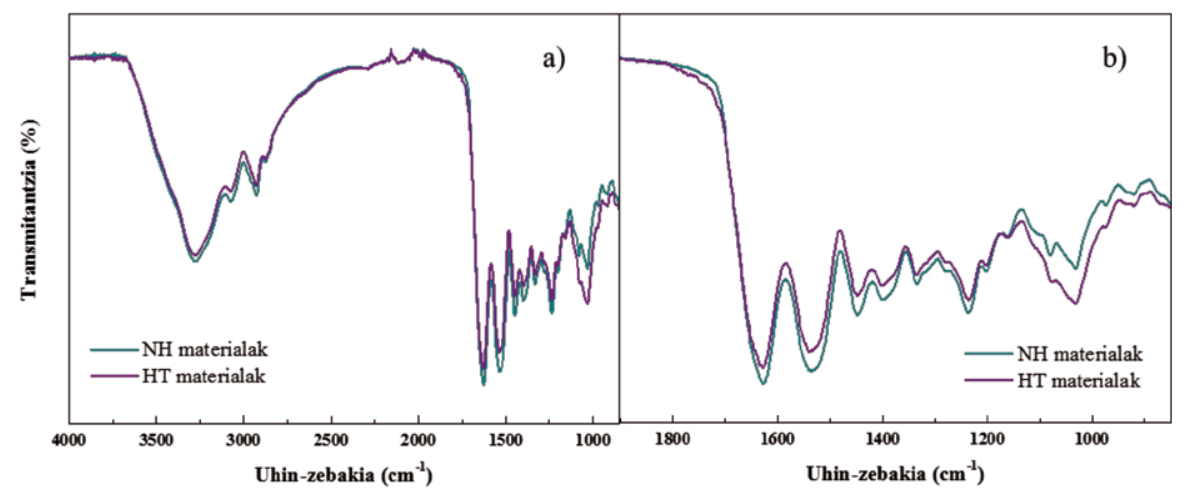

4. irudia. Bero tratamendua jasotako (HT) eta bero tratamendu gabeko $(\mathrm{NH})$ gelatinazko materialen FTIR espektroak, a) 4000-850 $\mathrm{cm}^{-1}$-eko tartean eta b) 2.000$850 \mathrm{~cm}^{-1}$-eko tartean.

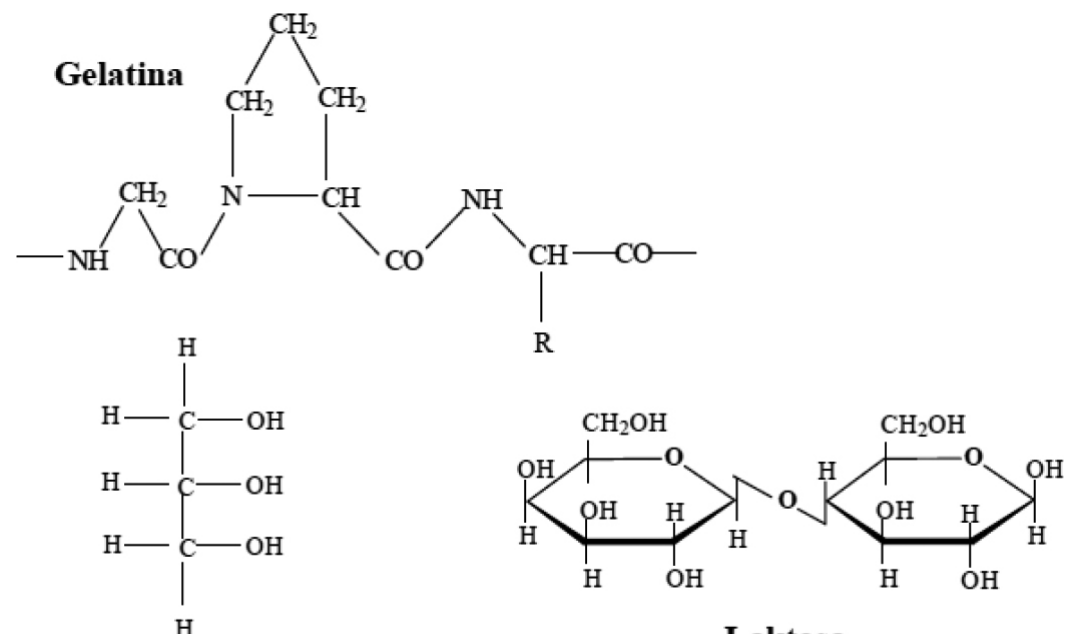

\section{Glizerola}

1. eskema. Gelatina, glizerola eta laktosaren egitura kimikoak.

\subsection{Ura xurgatzeko gaitasuna}

Materialen propietateetan saretze-erreakzioak eta manufaktura-teknikek eragin dezaketenez [24, 25], gelatinazko materialen ura xurgatzeko gaitasunean prozesatze-teknikek eta Maillard erreakzioak izandako eragina aztertu zen. Filmen eta scaffold-en kasuan, tratatu gabeko laginak (NH) PBS-an murgildu eta 30 minutura guztiz disolbatu egin ziren, bero- 
kuntza-tratamenduak sustatutako saretze-erreakzioak gelatinazko materialen urarekiko egonkortasuna hobetu zuela erakutsiz. Beraz, HT filmen eta scaffold-en ura xurgatzeko gaitasuna aztertu zen. Filmek (5a irudia) 5 minuturen ostean \% 230eko handitzea izan zuten, eta balioa iraunkorra zuten ondorengo 480 minutuetan.
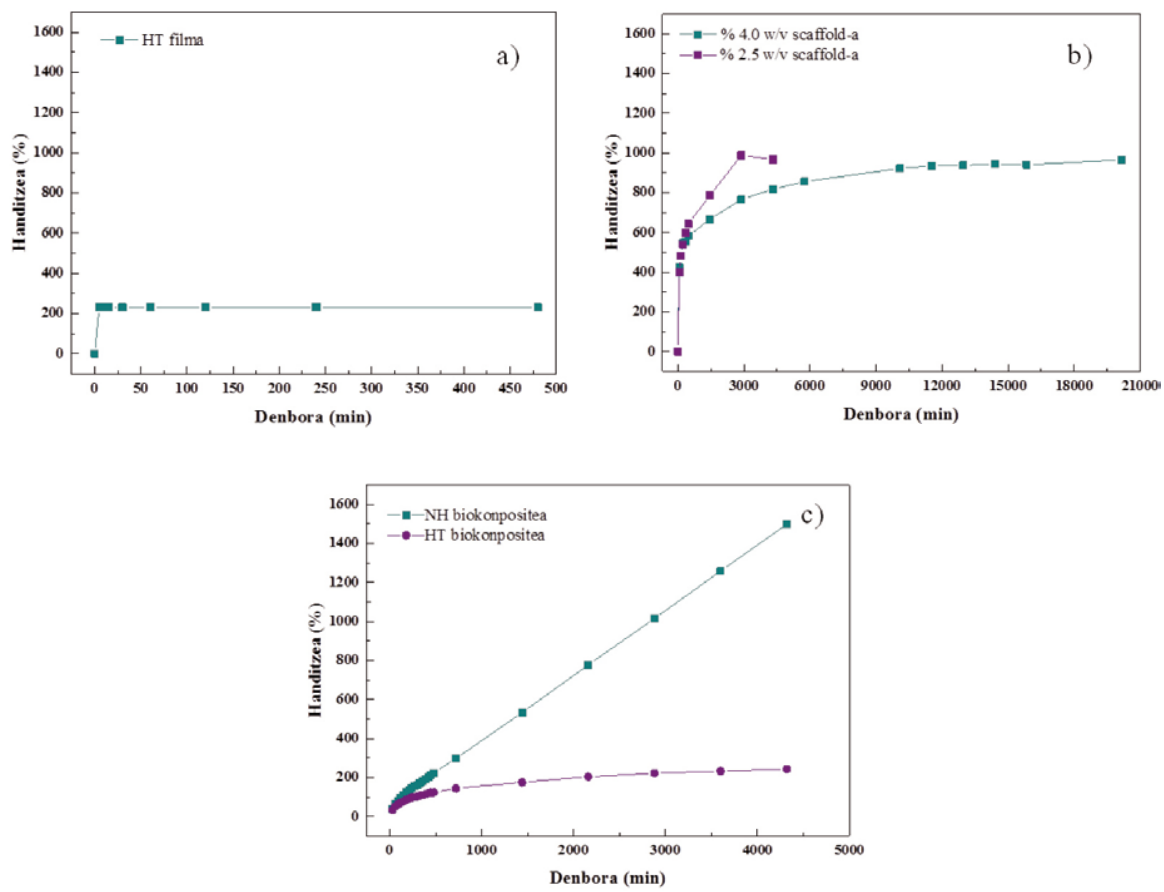

5. irudia. a) Bero-tratamendua jasotako (HT) filmen, b) \% 2,5 eta 4,0 HT scaffold-en, eta c) bero-tratamendurik gabeko $(\mathrm{NH})$ eta HT biokonpositeen handitzebalioak denboraren funtziopean.

Scaffold-en kasuan, berriz ( $5 \mathrm{~b}$ irudia), ura xurgatzeko ahalmena eta urarekiko egonkortasuna hasierako gelatinaren kontzentrazioaren funtziopean zeudela ikus daiteke. Nahiz eta bi kontzentrazioetan murgilpena eta 60 minutura scaffold-en handitzea \% 400ekoa izan, \% 4,0 laginek denbora gehiago behar izan zuten \% 2,5 laginen handitze-balio berera iristeko ( \% 800). Gainera, \% 4,0 scaffold-ek urarekiko egonkortasun altuagoa erakutsi zuten ( > $20.100 \mathrm{~min}$ ) \% 2,5 laginek baino (4.320 min). Hau scaffoldetan gelatinak harturiko bolumenarekin erlazionatu zen. Zenbat eta gelatina kantitate handiagoa eduki, likidoak, gure kasuan PBS-ak, denbora gehiago behar du materialaren barrualdera sartzeko, ura xurgatzeko gaitasunean eta materialaren egonkortasunean eraginez. Hala ere, bi kasuetan, handitze-balio oso handiak lortu ziren. 
Biokonpositeen handitzea aztertu zenean (5c irudia), NH laginak urarekiko egonkortasun handiagoa (> $4.000 \mathrm{~min}$ ) erakutsi zuten filmek eta scaffold-ek baino $(\sim 30 \mathrm{~min})$. Honek erakusten du saretze-erreakzioak bezala, manufaktura metodoak amaierako materialaren propietateetan eragina duela. NH laginak 480 minuturen ostean \% 230, eta 4.320 minuturen ostean \% 1.500 handitu ziren, handitze lineala denboran zehar erakutsiz. Aldiz, bero tratamenduak sustatutako saretze-erreakzioagatik, HT biokonpositeen handitzea esanguratsuki txikitu zen, 480 minutuan \% 150eko balioak eta 4.320 minutuan \% 250 inguruko balio konstanteak lortuz. Emaitza hauek erakusten dute gelatinazko laginen ur molekula kantitateak xurgatzeko gaitasuna hasierako formulazio bidez, saretze-erreakzio bidez eta manufakturazio teknikaren arabera kontrola daitezkeela.

\subsection{Ekorketazko elektroi-mikroskopia (SEM)}

Saretze-erreakzioaren eta manufaktura-prozesuen eragina gelatinazko materialen egitura-aldaketetan sakonki aztertzeko, SEM analisia burutu zen; 6. irudian erakusten dira filmen, scaffold-en eta biokonpositeen zeharkako sekzioen irudiak. Filmen kasuan (6a eta $6 \mathrm{~b}$ irudiak), Maillard saretze-erreakzioa gertatu zenean (6b irudia), zeharkako sekzioko irudiek egituraren aldaketa nabaria erakutsi zuten. Izan ere, HT filmetan erdigune leunagoa eta homogeneoagoa ikusi zen. Porositate txikiko egitura filmen ura xurgatzeko gaitasunarekin erlaziona daiteke. Izan ere, zenbat eta porositate txikiagoa izan, PBSak tarte gutxiago dauka materialaren barrualdera iristeko. Horregatik eta saretze-erreakzioagatik nagusiki, ura xurgatzeko gaitasun txikiena erakutsi zuten HT filmek.

Liofilizazio-prozesu bidez lorturiko scaffold-etan, berriz (6c-f irudiak), porositate eta poro handiko materialak lortu zirela ikusi zen. Izan ere, liofilizazio,prozesua materialen barruko aldean hutsune asko sortzeko metodo oso eraginkorra da. Porositatea hasierako gelatinaren kontzentrazioaren funtziopean zegoela ere ikus daiteke. Hasierako gelatinazko disoluzioaren kontzentrazioa handitzean, gelatina berak harturiko bolumena ere handitzen da, amaierako materialaren porositatean [26] eta, aurretik ikusi dugun bezala, ura xurgatzeko gaitasunean eraginez. Gelatinaren kontzentrazioa igo zenean (6e eta $6 \mathrm{f}$ irudiak), uretan egonkorragoak ziren porositate txikiagoko eta poro handiagoko scaffold-ak lortu ziren, zelulen nutrizio-horniketa erraztu dezakeen biomaterialen propietateak erakutsiz. Bestetik, berriz, gelatina-kontzentrazio baxuko (6c eta $6 \mathrm{~d}$ irudiak) ura xurgatzeko gaitasun handiagoko baina egonkortasun txikiagoko scaffold-ek porositate handiagoko eta poro txikiagoko egitura homogeneoagoa erakutsi zuten, zelulen itsasketarako gainazal gehiago izanik eta, beraz, ehun-ingeniaritzan erabiltzeko biomaterialen propietateak erakutsiz [27]. Bi kasuetan, bero-tratamenduaren ostean (6d eta $6 \mathrm{f}$ irudiak) porositate handiagoko scaffold-ak lortu ziren. 

materialen propietateetan
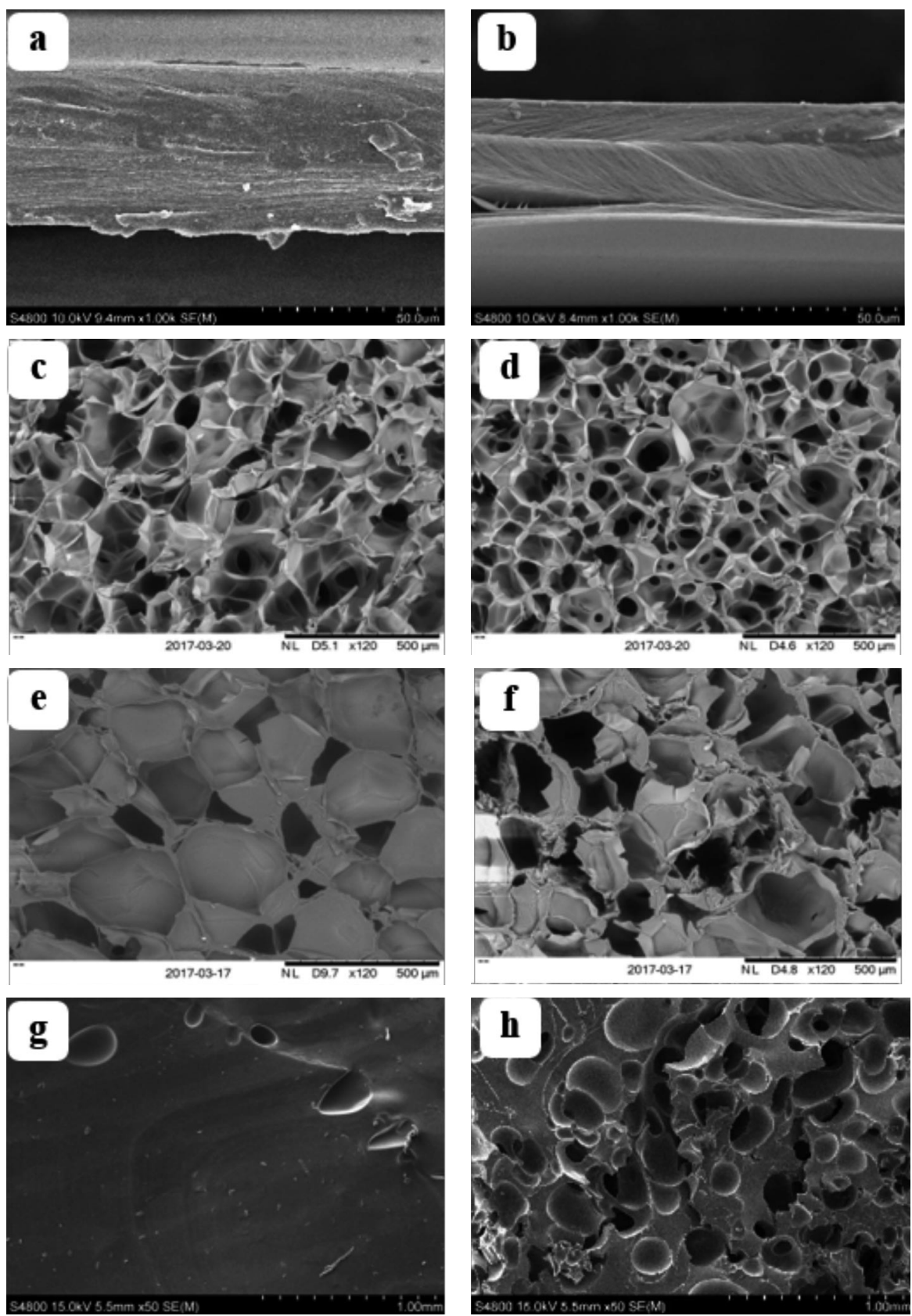

6. irudia. a) Bero-tratamendurik gabeko $(\mathrm{NH})$ eta b) bero-tratamendua jasotako (HT) gelatinazko filmen, c) NH eta d) HT \% 2,5 eta e) NH eta f) HT \% 4,0 gelatinazko scaffold-en, eta g) NH eta h) HT gelatinazko biokonpositeen zeharkako sekzioetako SEM irudiak. 
Gelatinazko biokonpositeen kasuan ( $6 \mathrm{~g}$ eta $6 \mathrm{~h}$ irudiak), berotu gabeko laginetan hutsune batzuk zituen gainazal homogeneoak eta leunak lortu ziren (6g irudia). Nahiz eta NH biokonpositeen erdigunea leunagoa eta porositate txikiagokoa izan, material hauek ura xurgatzeko ahalmen izugarria erakutsi zuten gelatinaren eta laktosaren artean Maillard erreakziorik sustatu ez zelako. Aldiz, berokuntzaren ostean eta biokonpositeak PBS soluzioan sartu ondoren, egitura oso porotsuak ikusi ziren (6h irudia). Egitura porotsu horiek, zelulen hazkuntzarako egokiak izateaz gain, konposatu aktiboak, hala nola antioxidatzaileak edota hanturaren kontrako molekulak, garraiatzeko interesgarriak izan daitezke, gelatinazko materialak elikagaien iraungitzea luzatzeko edota ebakuntza ondorengo hantura kontrolatzeko aplikazioetan erabiltzeko aukera ahalbidetuz.

\section{ONDORIOAK}

Lan honetan, gelatinazko filmak, scaffold-ak eta biokonpositeak industria teknika ezberdinen bidez prestatzeaz gain, gelatinaren urarekiko sentikortasuna hobetzeko materialak laktosarekin erreakzionarazi ziren, Maillard saretze-erreakzioa bero tratamendu bidez bultzatuz. Maillard erreakzioak gelatinazko materialetan eragindako aldaketa kimikoak FTIR espektroen $1.100-1.000 \mathrm{~cm}^{-1}$-eko tartean ikusteaz gain, HT filmen eta scaffold-en urarekiko egonkortasunak gelatinaren eta laktosaren arteko erreakzio kimikoa baieztatu zuen. Horretaz gain, ikusi zen saretze-erreakzioak NH biokonpositeen ura xurgatzeko ahalmena $\% 1.500$ etik \% 250era esanguratsuki txikitu zuela. Aipatzekoa da, era berean, prozesatze-teknikek NH biokonpositeen urarekiko egonkortasunean eta gelatinazko materialen egituran nabarmenki eragin zutela: filmen kasuan erdigune leunagoa eta homogeneoagoa ikusi ziren eta scaffold-en eta biokonpositeen kasuan, berriz, material porotsuak lortu ziren Maillard erreakzioaren ostean. Honekin guztiarekin, hasierako formulazioaren, erabilitako manufaktura tekniken eta saretze-erreakzioaren arabera, aplikazio zehatzetarako eskakizunen araberako propietate jakineko gelatinazko materialak ekoitz daitezkeela ondoriozta daiteke.

\section{ESKER ONAK}

Euskal Herriko Unibertsitateak (PPG17/18), Gipuzkoako Foru Aldundiak (Ekonomia Sustapeneko, Landa Inguruneko eta Lurralde Orekako Departamentua) eta Eusko Jaurlaritzak (Elikagaien Kalitate eta Industriako Zuzendaritza) emandako diru laguntzak eskertzen dituzte egileek. Hurrenez hurren, Alaitz Etxabidek Euskal Herriko Unibertsitateak (DOCREC17/04) eta Jone Urangak Eusko Jaurlaritzak (PRE_2015_1_0205) emandako dirulaguntzak eskertu nahi dituzte. 


\section{BIBLIOGRAFIA}

[1] MACARTHUR, D., WAUGHRAY, D., STUCHTEY, M. 2016. «The New Plastics Economy, Rethinking the Future of Plastics». In World Economic Forum.

[2] LECETA, I., ETXABide, A., CABEZUdo, S., DE LA CABA, K., GUERRERO, P. 2014. «Bio-based films prepared with by-products and wastes: environmental assessment». Journal of Cleaner Production, 64, 218227.

[3] BRAVIN, B., PERESSINI, D., SENSIDONI, A. 2006. «Development and application of polysaccharide-lipid edible coating to extend shelf-life of dry bakery products». Journal of Food Engineering, 76, 280-290.

[4] LOPEZ-RUBIO, A., LAGARÓN, J. M., eta OCIO, M. J. 2008. Active polymer packaging of non-meat food products. In: Smart packaging technologies for fast moving consumer goods. John Wiley and Sons, Ltd., UK.

[5] HANANI, Z. N., ROOS, Y., KERRY, J. 2014. «Use and application of gelatin as potential biodegradable packaging materials for food products». International Journal of Biological Macromolecules, 71, 94-102.

[6] PARK, S. B., LIH, E., PARK, K. S., JOUNG, Y. K., HAN, D. K. 2017. «Biopolymer-based functional composites for medical applications». Progress in Polymer Science, 68, 77-105.

[7] KROCHTA, J. M. 2002. Proteins as raw materials for films and coatings: definitions, current status, and opportunities. In: Protein-based films and coatings. CRC Press, Boca Raton.

[8] SANTORO, M., TATARA, A. M., MIKOS, A. G. 2014. «Gelatin carriers for drug and cell delivery in tissue engineering». Journal of Controlled Release, 190, 210-218.

[9] HAMMANN, F., SCHMID, M. 2014. «Determination and quantification of molecular interactions in protein films: A review». Materials, 7, 7975-7996.

[10] GUDIPATI, V. 2013. Fish gelatin: a versatile ingredient for the food and pharmaceutical industries. In: Marine Proteins and Peptides: Biological Activities and Applications. John Wiley and Sons, Ltd., UK.

[11] GÓMEZ-GUILLÉN, M., GIMÉNEZ, B., LÓPEZ-CABALLERO, M. A., MONTERO, M. 2011. «Functional and bioactive properties of collagen and gelatin from alternative sources: A review». Food Hydrocolloids, 25, 18131827.

[12] BENJAKUL, S., KITTIPHATTANABAWON, P., REGENSTEIN, J. M. 2012. Fish gelatin. In: Food Biochemistry and Food Processing. John Wiley and Sons, Ltd., UK.

[13] BERGO, P., SOBRAL, P. 2007. «Effects of plasticizer on physical properties of pigskin gelatin films». Food Hydrocolloids, 21, 1285-1289.

[14] KARIM, A., BHAT, R. 2008. «Gelatin alternatives for the food industry: recent developments, challenges and prospects». Trends in Food Science \& Technology, 19, 644-656. 
[15] DE CLERCQ, K., SCHELFHOUT, C., BRACKE, M., DE WEVER, O., VAN BOCKSTAL, M., CEELEN, W., REMON, J. P., VERVAET, C. 2016. «Genipin-crosslinked gelatin microspheres as a strategy to prevent postsurgical peritoneal adhesions: In vitro and in vivo characterization». Biomaterials, 96, 33-46.

[16] REDDY, N., REDDY, R., JIANG, Q. 2015. «Crosslinking biopolymers for biomedical applications». Trends in Biotechnology, 33, 362-369.

[17] ETXABIDE, A., URDANPILLETA, M., GUERRERO, P., DE LA CABA, K. 2015. «Effects of cross-linking in nanostructure and physicochemical properties of fish gelatins for bio-applications». Reactive and Functional Polymers, 94, 55-62.

[18] LIN, L. H., CHEN, K. M., LIU, H. J., CHU, H. C., KUO, T. C., HWANG, M. C., WANG, C. F. 2012. «Preparation and surface activities of modified gelatin-glucose conjugates». Colloids and Surfaces A: Physicochemical and Engineering Aspects, 408, 97-103.

[19] ASTM D570-98. 1998. «Standard test method for water absorption of plastics». In: Annual Book of ASTM Standards, American Society for Testing Materials.

[20] MARTÍNEZ-RUVALCABA, A., BECERRA-BRACAMONTES, F., SÁNCHEZ-DÍAZ, J. C., GONZÁLEZ-ÁLVAREZ, A. 2009. «Polyacrylamide-gelatin polymeric networks: effect of $\mathrm{pH}$ and gelatin concentration on the swelling kinetics and mechanical properties». Polymer Bulletin, 62, 539548.

[21] SCHMIDT, V., GIACOMELLI, C., SOLDI, V. 2005. «Thermal stability of films formed by soy protein isolate-sodium dodecyl sulfate». Polymer Degradation and Stability, 87, 25-31.

[22] WANG, W. Q., BAO, Y. H., CHEN, Y. 2013. «Characteristics and antioxidant activity of water-soluble Maillard reaction products from interactions in a whey protein isolate and sugars system». Food Chemistry, 139, 355-361.

[23] BASU, S., SHIVHARE, U., SINGH, T., BENIWAL, V. 2011. «Rheological, textural and spectral characteristics of sorbitol substituted mango jam». Journal of Food Engineering, 105, 503-512.

[24] HENNINK, W. E., VAN NOSTRUM, C. F. 2012. «Novel crosslinking methods to design hydrogels». Advanced Drug Delivery Reviews, 64, 223-236.

[25] AHMED, E. M. 2015. «Hydrogel: Preparation, characterization, and applications: A review». Journal of Advanced Research, 6, 105-121.

[26] WU, X., LIU, Y., LI, X., WEN, P., ZHANG, Y., LONG, Y., WANG, X., GUO, Y., XING, F., GAO, J. 2010. «Preparation of aligned porous gelatin scaffolds by unidirectional freeze-drying method». Acta Biomaterialia, 6, 1167-1177.

[27] JAFARI, M., PAKNEJAD, Z., RAD, M. R., MOTAMEDIAN, S. R., EGHBAL, M. J., NADJMI, N., KHOJASTEH, A. 2017. «Polymeric scaffolds in tissue engineering: a literature review». Journal of Biomedical Materials Research Part B: Applied Biomaterials, 105, 431-459. 